
\title{
25 Research Square \\ Enhanced Virulence of Salmonella enterica serovar Enteritidis ATCC13076 under Acid Stress by Global Transcriptomics
}

Hong Bai

South China University of Technology

Donggen Zhou

Ningbo International Travel Healthcare Center

Shuangfang Hu

South China University of Technology

Xiaowei Zhang

South China University of Technology

Qijun Liu

South China University of Technology

Xinglong Xiao ( $\sim$ fexxl@scut.edu.cn )

South China University of Technology https://orcid.org/0000-0001-5173-4459

Yigang Yu

South China University of Technology

Xiaofeng Li

South China University of Technology

\section{Research Article}

Keywords: virulence, pathogenicity, infection, $\mathrm{HCl}$ stress, foodborne pathogen

Posted Date: February 23rd, 2021

DOI: https://doi.org/10.21203/rs.3.rs-216400/v1

License: (1) This work is licensed under a Creative Commons Attribution 4.0 International License. Read Full License 


\section{Abstract}

Salmonella enterica serovar Enteritidis is a primary pathogen causing foodborne diseases and intestinal inflammatory responses. Acid tolerance response (ATR), as a strategy of adaption and resistance to acid stress, may contribute to enhanced virulence. In this study, there was a moderately acid adaption (pH 5.0) for $S$. Enteritidis cells prior to treatment with acid stress $(\mathrm{pH} 3.0)$. To figure out whether $S$. Enteritidis up-regulated the virulence or not, a global transcriptomic analysis was carried out by high-throughout RNA-sEq. The results showed 74 differentially expressed genes (DEGs) involved in virulence were identified after acid stress, among which, 62 DEGs were up-regulated and 12 DEGs were down-regulated. Afterwards, those virulence-linked DEGs were discussed and classified into four aspects based on the steps of infection, including flagellar functions, fimbrial adhesins, T3SS-mediated invasion and other virulent determinants. In conclusion, $S$. Enteritidis seemed to exhibit a trend of virulent genes towards high-expression under acid stress, revealing risks of Salmonella in acid-containing food. To our knowledge, there were few studies on comprehensively analyzing virulent genes expression changes of Salmonella, but it's novel to put forward pathogenicity as the highest priority under acid environment.

\section{Introduction}

Throughout the world, Salmonella enterica serovar Enteritidis and Typhimurium respectively ranking as the first and second places of the common serovars, are linked with outbreaks of human salmonellosis (Hendriksen et al. 2011). In spite of most studies focusing on $S$. Typhimurium, there are few on $S$. Enteritidis, which is responsible for some foodborne diseases and intestinal inflammatory responses. A survey about the worldwide distribution in human cases (Ekdahl et al. 2005), suggested $S$. Enteritidis is the most prevalent serovar in all but Africa, India and America. Besides, there have happened a series of outbreaks triggered by $S$. Enteritidis (Mandilara et al. 2017; Pavlova et al. 2018; Wright et al. 2015). Since researchers realized this serotype posed great risks to food industry and public health, a great many relevant reports have been published to figure out the mechanisms of the virulence.

The flagellum is a required multifunctional complex to enable the cells motility of swarming and swimming, and its functions involve attachment and adhesion, colonization, biofilm formation, as well as chemotaxis (Oguri et al. 2019). After approaching to the targets, Salmonella deploy a variety of adhesive structures in its surface at the initial step. In a review, Wagner and Hensel (2011) have systematically elucidated those structures including fimbriae, flagellum and other non-fimbrial adhesins, participating in specificity of adhesion to the host cells and cooperating with other virulence determinants. Gene clusters of fimbriae, including fim, csg, pef and Ipf (Ledeboer et al. 2006), contributed directly to its functions to a certain extent. Besides, lipopolysaccharide (LPS) and translocon proteins in T3SS are a second form of adhesins (Wagner and Hensel 2011).

In terms of the pathogenicity of Salmonella, the genes located on pathogenicity islands were attached great importance to. With the progress of research on pathogens, type III secretion system (T3SS) was believed to exist in some bacteria as a sophisticated machine that could attack and invade eukaryotic cells to manipulate the host cells, including Salmonella. The invasion is achieved with a needle-shaped structure, a vital component of T3SS, to deliver virulent proteins termed "effectors" (Cascales 2017). It was confirmed that 
Salmonella pathogenicity island 1 and 2 (SPI-1,2) encoded T3SS-1,2 that synthesized two types of effectors respectively. The effectors translocated by T3SS-1 are required for invasion into host cells and Salmonellacontaining vacuole (SCV) biogenesis, such as SopA, SopB, SopD, SopE (Fabrega and Vila 2013). While T3SS-2 effectors are linked to SCV maturation, replication and achievement of infection inside host cells, including SseL, SifA, SopD2, SopE2 and PipB2 (McGhie et al. 2009). SopA, a HECT-type E3 ligase, plays a key role in the stimulation of inflammation when an animal is infected with Salmonella Typhimurium. (Kamanova et al. 2016). SopD was found to directly bind to the InvC ATPase (Boonyom et al. 2010). SopE is a guanidyl exchange factor (GEF) for Rac1 and Cdc42, secreted by the T3SS-1 upon host cell contact and promotes entry through triggering of actin-dependent ruffles (Vonaesch et al. 2014). SseL is retained predominantly in the cytoplasm of infected cells following translocation by the T3SS (Coombes et al. 2007). SifA is related to localize to Salmonella-induced filaments (SIFs) and enables continuous fusion of host vesicles to SCV membranes (Knuff and Finlay 2017).

A series of stresses have been verified to render Salmonella to adjust its pathogenicity as survival strategies. For instance, Shah et al. (2012) performed an experiment in which acid and oxidative stresses impaired intestinal colonization and systemic dissemination in orally inoculated chickens. Meanwhile, the study showed the stress-resistance significantly changed the expression of some virulence genes. Especially, Salmonella have already acquired the ability to survive acid environment such as the gastrointestinal tract of their hosts. Acid tolerance response (ATR) depends on various strains (Lianou et al. 2017), types acid and its acidity (Alvarez-Ordonez et al. 2009), duration and so on. The virulent aspect of ATR remains ambiguous over $S$. Enteritidis, posing a great threat to the safety of acidic food and beverages. The molecular understanding of $S$. Enteritidis pathogenicity under acid stress is necessary for further insight and food industry.

\section{Results}

1 Data processing and DEGs analysis

After filtration and processing, the results showed the basic data of RNA sequencing, which suggested they are qualified and credible for following analysis and discussion. According to the threshold of log2(FC) foldchange $\geq 1, F D R<0.05,554$ DEGs were identified under acid stress. And then, 74 DEGs involved in virulence were classified and analyzed referring to the description of genes, Fabrega and Vila (2013), Wagner and Hensel (2011), as well as using the website (http://www.mgc.ac.cn/cgi-bin/VFs/genus.cgi?Genus=Salmonella). Among those selected DEGs, 62 DEGs were up-regulated and 12 DEGs were down-regulated, shown in the volcano plots diagram (Fig. 1).

\section{$2 \mathrm{GO}$ analysis classification of DEGs}

GO analysis (Quinteiro-Filho et al. 2012) were employed to classify the functions of identified DEGs. GO analysis results showed the percentage (number) of virulence-associated DEGs in various parts of cellular component, molecular function and biological process according to GO database (Gelli et al. 2017). Within cellular component, a big part of DEGs which were related to cell projection and bacterial-type flagellum 
accounted for the first two largest clusters. And in the category of biological process, a high percentage of DEGs existed in locomotion and cell process, as well as biological adhesion.

3 KEGG analysis classification of DEGs

In order to understand the virulent responses of acid mediated pathways in ATR. KEGG pathway enrichment analysis was also conducted. According to results of analysis, pathways including flagellar assembly, bacterial secretion system, bacterial chemotaxis, lipopolysaccharide biosynthesis and biofilm formation were in significant up-regulation under such an acid stress.

4 Validation of DEGs using qRT-PCR

In order to testify if the results of RNA-seq was in accord with the qPCR, some DEGs were analyzed through qPCR. Nine genes that include 7 up-regulated and 2 down-regulated genes were selected for the qRT-PCR analysis and used to validate the RNA-seq data from the preliminary experiment. It was shown in Fig. 2 that qRT-PCR data correlated well with the RNA-seq data $\left(R^{2}=0.9117\right)$. Totally, the qRT-PCR data were paralleled to those of RNA-seq aiming at these genes, in spite that the specific values of fold-change were different.

\section{Discussion}

As a consequence of virulence potentials and the high incidence of Salmonella-specific infections, we put forward virulence of $S$. Enteritidis to be the highest priority in this study. Generally, the infection caused by Salmonella should be attributed to several virulent structures, such as flagellum, fimbriae, T3SS-mediated invasion, lipopolysaccharide (LPS) and regulators. On the other hand, different structures are responsible for different processes and functions as follows.

1 Up-regulated flagellar genes

In Salmonella, flagellum plays a crucial role in infection, especially in the initial phase, such as colonization and attachment to the intestinal epithelium (Barbosa et al. 2017; Salehi et al. 2017). The two major functions of flagellum include motility and chemotaxis. The synthesis and function of the flagellar and chemotaxis system requires the expression of more than 50 genes or at least 17 operons ( $f h$, flg, fli, flj, mot, che, tar, tsr, and aer) that constitute the large and coordinately regulated flagellar regulon (Chilcott and Hughes 2000). It is demonstrated in Fig. 3 that flagellum consists of three parts, filament, hook, and basal body. Main component proteins of filament and hook are FliCD and FlgE respectively, and the latter one is regulated by FliK and FlgD. While $f h$ and flj didn't show a significant up-regulation. In our study, fliC was up-regulated by 2.13 and fliD by $1.48 \log _{2}(F C)$, as well as flgE by 1.05 . Crawford et al. (2010) reported that FliC can mediate binding to cholesterol and initiating biofilm formation, suggesting flagella enhanced bacterial adhesion. The center part of basal body is type III injectisome, a sophisticated nanomachine similar to T3SS (Erhardt et al. 2010). Flil (+ $\left.1.32 \log _{2}(\mathrm{FC})\right)$ was identified as an ATPase along with FliH $\left(+1.24 \log _{2}(\mathrm{FC})\right)$, both involved in the apparatus of type III injectisome (Minamino 2014). Apart from the structure protein described above, proximal rod (FlgB, $\mathrm{FlgC}$ and FlgF), MS ring (FliF) along with $\mathrm{C}$ ring (FliG) distinctly had an up-regulation by $1.09 \sim 1.44 \log _{2}(\mathrm{FC})$. 
Chevance and Hughes (2008) have elaborated on the mechanism of flagellar assembly: a three-tier hierarchy regulation. According to our data, in spite of the first class genes (flhDC operon) not showing different expressions, the high-expressed FliA by 1.19 and FliZ by $1.13 \log _{2}(\mathrm{FC})$, both of which belonged to class 2 . And FliA was identified as the sigma factor $\left(\sigma^{28}\right)$ of flagellar genes, while FliZ as the expression activator to regulate its own class genes (Tanabe et al. 2011). Actually, class 2 proteins couldn't express in absence of $\mathrm{FlhD}_{4} \mathrm{C}_{2}$ revealing a fact that $f h D C$ operon had finished its work in earlier stage as shown in Fig. 3 (Barker et al. 2014). In addition, flgANM and fliT were all significantly up-regulated coincidently in varying levels ranging from 1.02 to $1.50 \log _{2}(F C)$. Prior to the completion of class 2 assembly (Fig. 3), the anti- $\sigma^{28}$ factor FlgM regulated the expression of late substrate genes under regulation of class 3 promotor and hook-associated genes (flgKL and fliD) (Erhardt et al. 2010). Moreover, genes of chemotaxis (cheYZ, tsr and aer) were also respectively up-regulated by $1.24,1.191 .37$ and $1.12 \log _{2}(\mathrm{FC})$ under acid stress. Whereas the motility genes ( $m o t A B$ ) did not appear a significant up-regulation as expectation. Obviously, what are listed above offers the amplest evidence that flagella functioned better in such extreme situation.

2 Fimbriae-linked genes were slightly up-regulated

Previous to Salmonella's invasion into host cells, fimbriae is a required and decisive structure to adhere to cell membrane. As shown in Table 2, S. Enteritidis up-regulated majority of genes involved in fimbrial assembly, transporter, structure, regulator and chaperone/usher protein. Fimbrial adhesins are produced in following three pathways referring to Wagner and Hensel (2011): chaperone-usher pathway, the extracellular nucleation pathway and type IV pili. fimD and fiml, members of type I fimbriae (SEF21) family, generally appeared a downregulation by 1.06 and $1.54 \log _{2}(\mathrm{FC})$, however, fimF was up-regulated by $1.36 \log _{2}(\mathrm{FC})$. Another type of fimbriae-SEF14- existed specifically in $S$. Enteritidis. It turned out to be three genes (sefABC) in SEF14 operon. SEF14 fimbriae contributes to SE adherence with mouse epithelial cells but not to human HEp-2, Caco-2, INT407, or HeLa cells (Quan et al. 2019). SefA, a novel fimbrin, owns the ability to enhance $S$. Enteritidis adhesion to epithelial cells and survival in macrophages and results in S. Enteritidis virulence in mice (Zhu et al. 2013). SefB and SefC shared homology with E. coli fimbrial chaperone and outer membrane proteins (Clouthier et al. 1993). From our results, $\operatorname{sef} A B C$ was up-regulated by $1.54,1.45$ and $1.90 \log _{2}(\mathrm{FC})$, respectively. In addition, type IV pili genes seemed to be regulated during acid stress, hofC showing a down-regulation by 1.46 and pilCN by 1.67 and 1.00 except for SEN1977. As far as long polar fimbriae (Lpf) was concerned, it was firstly proposed to role in the adhesion of $S$. Typhimurium to cells of the Peyer's patches (Bäumler et al. 1996). In our study, IpfA acting as a precursor of long polar fimbrial protein A up-regulated by $2.09 \log _{2}(\mathrm{FC})$ than unstressed cells. Such abundance of expression suggested the cells were likely to up-regulate the subsequent genes $(I p f C D)$ in the next steps. On the other hand, Salmonella can specifically assemble curli fiber or thin aggregation fimbriae (Tafi) via the nucleation-participation pathway like E. coli. Curli fimbriae relates to adhesion, induction of proinflammatory response and biofim formation (Fabrega and Vila 2013). And CsgBA (subunits) and CsgDEFG are required for curli biogenesis, these two divergently transcribed operons are the homologues in E. coli (Römling et al. 1998). In a recent study (Newman et al. 2018), it was unraveled that regulator CsgD mediated stationary phase counter-silencing of $\operatorname{csg} B A$ in $S$. Typhimurium. Under acid stress, $S$. Enteritidis also up-regulated $\operatorname{csg} D$ by 1.84 and $c s g C$ by $1.71 \log _{2}(F C)$ in site of insignificance (FDR $\left.\geq 0.05\right)$, not shown in Table 2, as well as other protein with slightly up-regulation. Moreover, up-regulations of yehD encoding a fimbrial subunit protein and virF encoding a fimbrial operon positive regulatory protein reflected an 
active state of fimbriae. In total, roles of fimbriae in adhesion turned out to be a reasonable enhancement even though $S$. Enteritidis cells partly down-regulated type I fimbriae and type IV pilin.

$3 S$. Enteritidis up-regulated genes for invasion and infection

T3SS-1 was confirmed to enable Salmonella to invade into host epithelial cells and establishing infection in the gastrointestinal tract. T3SS-1 would not function completely until DsbA arrived its destination and activated the apparatus, which is required for translocation and secretion of effectors (Fabrega and Vila 2013). After treated with acid stress, $S$. Enteritidis slightly up-regulated $d s b A$ by $0.79 \log _{2}(\mathrm{FC})$. Initiation of actin cytoskeletal remodeling and induction of a proinflammatory response are attributed mainly to the effectors SopE, SopE2 that function as a guanidine exchange factor (GEF) for host cellular Rho GTPases (Hardt et al. 1998). Despite of the differences of their structures, these two proteins function in invasion into host cell identically. Our data shows $S$. Enteritidis up-regulated DsbA by 0.79 , SopE and SopE2 by $1.48 \log _{2}(\mathrm{FC})$. Two additional key SPI-1 effectors, SopA and SopD also contributing to enteropathogenesis. In this study, SopA was down-regulated by $1.13 \log _{2}(F C)$, while SopD was up-regulated by $2.04 \log _{2}(F C)$. Kamanova et al. (2016) concluded that sopA encodes a HECT-type E3 ligase, contributing to the stimulation of inflammation when an animal is infected with $S$. Typhimurium. It was reported SopD directly bound to the InvC ATPase and was found in the host-cell cytosol not only during the early stages of infection but also later in the SCV (Boonyom et al. 2010; Brumell et al. 2003). Moreover, SopD and SopB play role cooperatively in enhancing membrane fission and to promote micropinocytosis during $S$. Typhimurium invasion (Bakowski et al. 2007). In addition, T3SS encoded by SPI-2 generally functions and translocates effectors that participate in SCV maturation and establishment of infection within host cells. As shown in Table 2, there is an up-regulation of $1.19 \log _{2}(\mathrm{FC})$ for SseL. Such a T3SS-2 effector protein was reported to retain predominantly in the cytoplasm of infected cells following translocation by the T3SS (Coombes et al. 2007). PipB2 and SifB as another two translocated effectors of T3SS-2 were respectively up-regulated by 1.57 and $1.22 \log _{2}(\mathrm{FC})$. And it has been proven that PipB2 and SifB can localize to SIF and SCV membranes and result in subsequent infection (Freeman et al. 2003; Knuff and Finlay 2017). Apart from the effectors, SsaQ (type III secretion system protein), SseC (translocation machinery component), RcsC (secretion system regulator: Sensor component) and SEN3371 (pathogenicity island protein) were also significantly up-regulated by $1.01 \sim 1.43 \log _{2}(\mathrm{FC})$.

Surprisingly, inv, hilA, spt, spa, sip, iag, iac and sic that had a close connection with colonization and invasion of Salmonella referring to earlier studies (Bajaj et al. 1996; Boyd et al. 1997; Phoebe Lostroh and Lee 2001; Rahn et al. 1992), turned out to be no expression in either unstressed or stressed cells in our results. The unexpected phenomenon could attribute to the hierarchy of regulation of invasion. Gene regulation plays an extremely important role in the efficacy of the pathogenesis of Salmonella in order to coordinate all the virulence traits (Fabrega and Vila 2013). As shown in Fig. 4, this regulation is under a temporal hierarchy in which virulence elements need to be progressively expressed. In our study, $S$. Enteritidis mildly up-regulated HilD by $0.99 \log _{2}(F C)$, which was regarded as the most important activator of HilA in vitro and at the upper class of the hierarchy. Gene hilD was activated by FliZ and Fis, but repressed by CsrA, all the three type of regulator was up-regulated by $1.13 \sim 1.29$. And the presence of Hha (Nucleoid proteins) with an up-regulation of $1.39 \log _{2}(\mathrm{FC})$ absolutely repressed hilA, contributing to repression of $\mathrm{inv} / \mathrm{spa}$, $\mathrm{prg} / \mathrm{org}$, sic/ sip and some effectors. Furthermore, physiology of $S$. Enteritidis should be considered. If not in a period of invasion, it is not 
an economic alternative to maintain a high level of expression for these proteins. As a result, regulators such as DsbA and HilD made a greater contribution to the subsequent invasion, let alone the various effectors encoded by SPI-1 and SPI-2.

4 Other pathogenicity determinants were up-regulated

\subsection{LPS}

LPS, located in the outer layer of membrane, not only functions as a defender of cells, but is also identified as a key determinant of virulence involved in colonization (Nevola et al. 1985), invasion and self-protection from bacteria being killed by macrophages (Kong et al. 2011). It consists of three components, including lipid A, core oligosaccharide (C-OS), and O-antigen polysaccharide. The assembly system of C-OS A rfaL mutant of $S$. Typhimurium, which lacks the entire O-antigen (O-Ag), was virtually avirulent in a Galleria mellonella infection model (Bender et al. 2013). According to our data (Table 2), not only was rfaL up-regulated by $1.37 \log _{2}$ (FC). Besides, Kong et al. (2011) also elucidated $r f a G I H J L, ~ r f b P$ and $r f c$ encoded a series of expressions that were concerned with LPS's virulent aspect. The results showed that genes in Rfa, Rfb and Rfc families were upregulated by $1.17 \sim 2.23 \log _{2}(\mathrm{FC})$ except for RfaF's down-regulation by $1.20 \log _{2}(\mathrm{FC})$.

\subsection{Regulators}

Importantly, CsrA, a global post-transcriptional regulator controlling various properties related to metabolism and virulence, had a significant high-expression by $1.23 \log _{2}(\mathrm{FC})$. For instance, CsrA was proved to positively regulate FlhC and FlhD (Lawhon et al. 2003), both the subunits of the primary regulator in flagella expression, which didn't show an obvious up-regulation according to our data. Additionally, Sterzenbach et al. (2013) figured out that CsrA is a positive regulator of PefA expression in $S$. Typhimurium by binding a GGA motif in the 50-UTR of the pefACDEF transcript. Meanwhile, capability of regulating HilD leaves CsrA involved in invasion, especially in the expression of the T3SS part (Fortune et al. 2006).

In this study, marA and soxS was up-regulated by 2.37 and $1.27 \log _{2}$ (FC), respectively. MarA was proved to effect the invasion into host cells for $S$. Choleraesuis, when exposed to an environment of acid and bile salts (Lee et al. 2015). In E. coli, MarA and SoxS were both described as members of AraC family to regulate a great many proteins, when adapting to unfavorable conditions, including acid stress (Duval and Lister 2013). Another study also implicated that SoxS controlling expression of distinct genes acted as a key factor in persistence of E. coli in murine pyelonephritis (Casaz et al. 2006).

\section{Conclusion}

Altogether, by using global transcriptomic, we surprisingly found that $S$. Enteritidis enhanced its virulence after exposed to such an acid environment. We analyzed and divided results into four essential virulence-associated aspects, including flagellar functions, fimbriae-mediated adhesion, invasion of T3SS, virulent roles of LPS and some regulators. Each part showing an up-regulation contributed jointly and strongly to our conclusion that Salmonella Enteritidis had evolved the ability to cope with low pH environment such as the gastrointestinal tract of their hosts during infection. This study paid attention to a threat of Salmonella existing in acid food, as 
an inspiration for the food industry. Furthermore, it's valuable to figure out the mechanisms of virulent aspects in Salmonella.

\section{Material And Methods}

1 Bacterial strain and gastric fluid simulation

The strain used in this study was Salmonella enterica subsp. enterica serovar Enteritidis ATCC13076, stocked at $-80^{\circ} \mathrm{C}$ in Luria-Bertani (LB) with $30 \%$ glycerol. Initially, it was activated by streaking onto LB plate with incubation at $37^{\circ} \mathrm{C}$ for $24 \mathrm{~h}$ before each experiment. Then the exponential phase cells (OD600 $\left.\approx 1.0\right)$ were centrifuged at $5000 \times \mathrm{g}$ for $3 \mathrm{~min}$ and washed twice with sterilized phosphate buffer. Subsequently, the washed culture was dissolved in LB broth at a concentration of approximately $10^{6} \mathrm{CFU} / \mathrm{mL}$ (6 Log 10 culture).

Under acid stress, $S$. Enteritidis was pretreated with acid adaption as follows. Briefly, during acid adaption process, 6 Log10 culture was collected in the LB broth ( $\mathrm{pH} 5.5)$ for $1 \mathrm{~h}$. And immediately, the broth was changed to $\mathrm{pH} 3.0$ with $\mathrm{HCl}(1 \mathrm{M})$ or incubated for another hour. For the control, treatment in LB broth (pH 7.0) for $2 \mathrm{~h}$ was conducted. The temperature throughout the duration of above experiments was maintained at $37^{\circ} \mathrm{C}$.

2 RNA isolation and library construction

According to the instruction from manufacturer, the total RNA of $S$. Enteritidis in each sample was extracted by using the Trizol Kit (Promega, USA). There existed some DNA left in the total RNA to be degraded by RNase-free DNase I (Takara Bio, Japan) for $30 \mathrm{~min}$ at $37^{\circ} \mathrm{C}$. Results of RNase free agarose gel electrophoresis and an Agilent 2100 Bio-analyzer (Agilent Technologies, Santa Clara, CA) can testify if RNA isolation was of good quality. Afterwards, Poly (A) mRNA isolated by oligo-dT beads (Qiagen) was fragmented in the lysis buffer.

According to the fragmented mRNA, there generated the first-strand cDNA through random hexamer-primed reverse transcription. Subsequently, the synthesis of the second-strand cDNA took place in presence of RNase $\mathrm{H}$ and DNA polymerase I (Chen et al. 2016). A QIA quick PCR extraction kit was used to enable the purification of cDNA fragments. These purified fragments were subjected to EB buffer for end reparation poly (A) addition and ligated to sequencing adapters. At last, extraction, purification and enrichment of the ligated cDNA fragments were conducted by PCR aiming to construct cDNA library after agarose gel electrophoresis.

3 Sequencing and reads alignment

It was performed on the Illumina sequencing platform (Illumina HiSeq ${ }^{\mathrm{TM}} 2000$ ) to sequence the cDNA library with the pairedend technology applied (Gene Denovo Co. Guangzhou, China). A Perl program was employed to remove low quality sequences that refer to more than half of entire bases with quality lower than 20 or reads with more than $5 \% \mathrm{~N}$ bases ( $\mathrm{N}$ means bases unknown) and adaptor sequences (Chen et al. 2016). Short sequences alignment was conducted with SOAPaligner/soap2 paralleled to a previous research. These sequencing reads were subsequently mapped to reference sequence by the SOAPaligner/soap2 (Li et al. 2009). The expression statistics and visualization throughout this study was accomplished with the technical assistance of R package (http://www.r-project.org/). 
4 Differentially expressed genes (DEGs) and function enrichment analyses

The Bioconductor package edgeR (Robinson, McCarthy, \& Smyth, 2010) was employed in identifying of differential expression genes. As the false discovery rate (FDR) was to examine and filter out the genes without significance in differential expression, we applied a $p$ value, a threshold of the FDR $\leq 0.05$ and $\| \log _{2}$ Ratio| $\geq 1$ according to Chen et al. (2016).

Referring to a previous study (Zhang et al. 2013) with minor modification, the DEGs were then subjected to Gene Ontology (GO) and Kyoto Encyclopedia of Genes and Genomes (KEGG) enrichment analyses. Once a Pvalue was not more than 0.05 , we considered that both two methods have achieved a significant enrichment.

5 Quantitative real-time PCR (qRT-PCR) validations

It was 7500 Fast Real-Time PCR System (Applied Biosystem, Foster, USA) that was employed to justify the uniformity of gene expression between RNA-seq and qRT-PCR, with 9 DEGs selected. We regarded the 16 S RNA gene of $S$. Enteritidis as the internal control gene. In accordance with instruction manual, total RNA extraction was conducted with Trizol reagent, and the extracted RNA was instantly utilized in cDNA synthesis by using reverse transcriptase. Quantitation of each transcript was performed with total RNA in duplicate and the starting materials and each qPCR were conducted in triplicate.

Table 1 outlined the primer pairs used in qPCR analysis and some sequences for detection of $S$. Enteritidis derived from those of references with modifications.

\section{Declarations}

\section{Acknowledgement}

We thank Guangzhou Gene Denovo Biotechnology Co., Ltd., China, for technical assistance.

\section{Funding sources}

This work was supported by National Key Research and Development Program of China (grant number 2018 YFC1602201 and 2016YFF0203204), Science and Technology Program Foundation of Guangzhou, China (grant number 201904010077).

\section{Conflicts of interest}

Hong Bai, Donggen Zhou, Shuangfang Hu, Xiaowei Zhang, Qijun Liu, Xinglong Xiao, Yigang Yu and Xiaofeng Li declare that they have no conflict of interest.

\section{Availability of data and material}

Not applicable.

\section{Code availability}

Not applicable. 


\section{Authors' contributions}

Hong Bai and Donggen Zhou had substantial contributions to the experiments, as well as the processing and analysis of data in this study; Shuangfang Hu, Xiaowei Zhang, Qijun Liu and Xinglong Xiao helped with the analysis and interpretation of transcriptional data of the work. And finally, Yigang Yu and Xiaofeng Li revised the final draft of this article critically and made it acceptable for publication.

\section{References}

Alvarez-Ordonez A, Fernandez A, Bernardo A, Lopez M (2009) Comparison of acids on the induction of an Acid Tolerance Response in Salmonella typhimurium, consequences for food safety. Meat Science 81:65-70 doi:https://doi.org/10.1016/j.meatsci.2008.06.019

Bajaj V, Lucas RL, Hwang C, Lee CA (1996) Co-ordinate regulation of Salmonella typhimurium invasion genes by environmental and regulatory factors is mediated by control of hilA expression. Mol Microbiol 22:703-714 doi:https://doi.org/10.1046/j.1365-2958.1996.d01-1718.x

Bakowski MA, Cirulis JT, Brown NF, Finlay BB, Brumell JH (2007) SopD acts cooperatively with SopB during Salmonella enterica serovar Typhimurium invasion. Cell Microbiology 9:2839-2855 doi:https://doi.org/10.1111/j.1462-5822.2007.01000.x

Barbosa FdO et al. (2017) Contribution of flagella and motility to gut colonisation and pathogenicity of Salmonella Enteritidis in the chicken. Braz J Microbiol 48:754-759 doi:https://doi.org/10.1016/j.bjm.2017.01.012

Barker CS, Meshcheryakova IV, Inoue T, Samatey FA (2014) Assembling flagella in Salmonella mutant strains producing a type III export apparatus without FliO. J Bacteriol 196:4001-4011 doi:https://doi.org/10.1128/JB.02184-14

Bäumler AJ, Tsolis RM, Heffron F (1996) The Ipf fimbrial operon mediates adhesion of Salmonella typhimurium to murine Peyer's patches. Proceedings of the National Academy of Sciences of the United States of America 93:279-283 doi:https://doi.org/10.1073/pnas.93.1.279

Bender JK, Wille T, Blank K, Lange A, Gerlach RG (2013) LPS Structure and PhoQ Activity Are Important for Salmonella Typhimurium Virulence in the Gallleria mellonella Infection Model. PLOS ONE 8:e73287 doi:https://doi.org/10.1371/journal.pone.0073287

Boonyom R, Karavolos MH, Bulmer DM, Khan CM (2010) Salmonella pathogenicity island 1 (SPI-1) type III secretion of SopD involves $\mathrm{N}$ - and C-terminal signals and direct binding to the InvC ATPase. Microbiology 156:1805-1814 doi:https://doi.org/10.1099/mic.0.038117-0

Boyd EF, Li J, Ochman H, Selander RK (1997) Comparative genetics of the inv-spa invasion gene complex of Salmonella enterica. J Bacteriol 179:1985-1991 doi:https://doi.org/10.1128/jb.179.6.1985-1991.1997

Brumell JH, Kujat-Choy S, Brown NF, Vallance BA, Knodler LA, Finlay BB (2003) SopD2 is a novel type III secreted effector of Salmonella typhimurium that targets late endocytic compartments upon delivery into host 
cells. Traffic 4:36-48 doi:https://doi.org/10.1034/j.1600-0854.2003.40106.x

Casaz P, Garrity-Ryan LK, McKenney D, Jackson C, Levy SB, Tanaka SK, Alekshun MN (2006) MarA, SoxS and Rob function as virulence factors in an Escherichia coli murine model of ascending pyelonephritis. Microbiology 152:3643-3650 doi:https://doi.org/10.1099/mic.0.2006/000604-0

Cascales E (2017) Inside the chamber of secrets of the type III secretion system. Cell 168:949-951 doi:https://doi.org/10.1016/j.cell.2017.02.028

Chen L et al. (2016) High-resolution QTL mapping for grain appearance traits and co-localization of chalkiness-associated differentially expressed candidate genes in rice. Rice 9:1-17 doi:https://doi.org/10.1186/s12284-016-0121-6

Chevance FFV, Hughes KT (2008) Coordinating assembly of a bacterial macromolecular machine. Nature Reviews Microbiology 6:455-465 doi:https://doi.org/10.1038/nrmicro1887

Chilcott GS, Hughes KT (2000) Coupling of flagellar gene expression to flagellar assembly in Salmonella enterica serovar Typhimurium and Escherichia coli. Microbiol Mol Biol Rev 64:694-708 doi:https://doi.org/10.1128/MMBR.64.4.694-708.2000

Clouthier SC, Müller KH, Doran JL, Collinson SK, Kay WW (1993) Characterization of three fimbrial genes, sef $A B C$, of Salmonella enteritidis. J Bacteriol 175:2523-2533 doi:https://doi.org/10.1128/jb.175.9.25232533.1993

Coombes BK et al. (2007) SseL is a Salmonella-specific translocated effector integrated into the SsrBcontrolled Salmonella pathogenicity island 2 type III secretion system. Infect Immun 75:574-580 doi:https://doi.org/10.1128/IAI.00985-06

Crawford RW, Reeve KE, Gunn JS (2010) Flagellated but not hyperfimbriated Salmonella enterica serovar Typhimurium attaches to and forms biofilms on cholesterol-coated surfaces. J Bacteriol 192:2981-2990 doi:https://doi.org/10.1128/JB.01620-09

Duval V, Lister I (2013) MarA, SoxS and Rob of Escherichia coli - global regulators of multidrug resistance, virulence and stress response. International journal of biotechnology for wellness industries 2:101-124 doi:https://doi.org/10.6000/1927-3037.2013.02.03.2

Ekdahl K, de Jong B, Wollin R, Andersson Y (2005) Travel-associated non-typhoidal salmonellosis: geographical and seasonal differences and serotype distribution. Clin Microbiol Infect 11:138-144 doi:https://doi.org/10.1111/j.1469-0691.2004.01045.x

Erhardt M, Namba K, Hughes KT (2010) Bacterial nanomachines: The flagellum and type III injectisome. Cold Spring Harbor Perspectives in Biology 2:a000299 doi:https://doi.org/10.1101/cshperspect.a000299

Fabrega A, Vila J (2013) Salmonella enterica serovar Typhimurium skills to succeed in the host: virulence and regulation. Clin Microbiol Rev 26:308-341 doi:https://doi.org/10.1128/CMR.00066-12 
Fortune DR, Suyemoto M, Altier C (2006) Identification of CsrC and characterization of its role in epithelial cell invasion in Salmonella enterica serovar Typhimurium. Infect Immun 74:331-339

doi:https://doi.org/10.1128/IAl.74.1.331-339.2006

Freeman JA, OhI ME, Miller SI (2003) The Salmonella enterica serovar typhimurium translocated effectors SseJ and SifB are targeted to the Salmonella-containing vacuole. Infect Immun 71:418-427 doi:https://doi.org/10.1128/IAI.71.1.418-427.2003

Gelli M, Konda AR, Liu K, Zhang C, Clemente TE, Holding DR, Dweikat IM (2017) Validation of QTL mapping and transcriptome profiling for identification of candidate genes associated with nitrogen stress tolerance in sorghum. BMC Plant Biology 17:123 doi:10.1186/s12870-017-1064-9

Hardt WD, Chen LM, Schuebel KE, Bustelo XR, Galan JE (1998) S. typhimurium encodes an activator of Rho GTPases that induces membrane ruffling and nuclear responses in host cells. Cell 93:815-826 doi:https://doi.org/10.1016/S0092-8674(00)81442-7

Hendriksen RS, Vieira AR, Karlsmose S, Lo Fo Wong DM, Jensen AB, Wegener HC, Aarestrup FM (2011) Global monitoring of Salmonella serovar distribution from the World Health Organization Global Foodborne Infections Network Country Data Bank: results of quality assured laboratories from 2001 to 2007. Foodborne Pathogens and Disease 8:887-900 doi:10.1089/fpd.2010.0787

Kamanova J, Sun H, Lara-Tejero M, Galan JE (2016) The Salmonella effector protein SopA modulates innate immune responses by targeting TRIM E3 ligase family members. PLoS Path 12:e1005552 doi:https://doi.org/10.1371/journal.ppat.1005552

Knuff K, Finlay BB (2017) What the SIF is happening-the role of intracellular Salmonella-induced filaments. Frontiers in Cellular and Infection Microbiology 7 doi:https://doi.org/10.3389/fcimb.2017.00335

Kong Q, Yang J, Liu Q, Alamuri P, Roland KL, Curtiss R (2011) Effect of deletion of genes involved in lipopolysaccharide core and $\mathrm{O}$-antigen synthesis on virulence and immunogenicity of Salmonella enterica serovar Typhimurium. Infect Immun 79:4227 doi:https://doi.org/10.1128/IAI.05398-11

Lawhon SD, Frye JG, Suyemoto M, Porwollik S, McClelland M, Altier C (2003) Global regulation by CsrA in Salmonella typhimurium. Mol Microbiol 48:1633-1645 doi:https://doi.org/10.1046/j.1365-2958.2003.03535.x

Ledeboer NA, Frye JG, McClelland M, Jones BD (2006) Salmonella enterica serovar Typhimurium requires the Ipf, pef, and tafi fimbriae for biofilm formation on HEp-2 tissue culture cells and chicken intestinal epithelium. Infect Immun 74:3156 doi:https://doi.org/10.1128/IAI.01428-05

Lee J-J, Hsuan S-L, Kuo C-J, Wu Y-C, Chen T-H (2015) MarA and ramA regulate virulence in Salmonella enterica serovar Choleraesuis. Vet Microbiol 181:323-327 doi:https://doi.org/10.1016/j.vetmic.2015.09.006

Li R, Yu C, Li Y, Lam TW, Yiu SM, Kristiansen K, Wang J (2009) SOAP2: an improved ultrafast tool for short read alignment. Bioinformatics 25:1966-1967 doi:https://doi.org/10.1093/bioinformatics/btp336 
Lianou A, Nychas G-JE, Koutsoumanis KP (2017) Variability in the adaptive acid tolerance response phenotype of Salmonella enterica strains. Food Microbiol 62:99-105 doi:https://doi.org/10.1016/j.fm.2016.10.011

Mandilara G et al. (2017) A severe gastroenteritis outbreak of Salmonella enterica serovar Enteritidis PT8, with PFGE profile Xbal.0024 and MLVA profile 2-9-7-3-2 following a christening reception, Greece, 2016. Epidemiol Infect 146:28-36 doi:https://doi.org/10.1017/S0950268817002667

McGhie EJ, Brawn LC, Hume PJ, Humphreys D, Koronakis V (2009) Salmonella takes control: effector-driven manipulation of the host. Curr Opin Microbiol 12:117-124 doi:https://doi.org/10.1016/j.mib.2008.12.001

Minamino T (2014) Protein export through the bacterial flagellar type III export pathway. Biochim Biophys Acta 1843:1642-1648 doi:https://doi.org/10.1016/j.bbamcr.2013.09.005

Nevola JJ, Stocker BA, Laux DC, Cohen PS (1985) Colonization of the mouse intestine by an avirulent Salmonella typhimurium strain and its lipopolysaccharide-defective mutants. Infect Immun 50:152-159

Newman SL, Will WR, Libby SJ, Fang FC (2018) The curli regulator CsgD mediates stationary phase countersilencing of $\operatorname{csgBA}$ in Salmonella Typhimurium. Mol Microbiol 108:101-114 doi:https://doi.org/10.1111/mmi.13919

Oguri T et al. (2019) A family of small intrinsically disordered proteins involved in flagellum-dependent motility in Salmonella enterica. J Bacteriol 201:e00415-00418 doi:https://doi.org/10.1128/JB.00415-18

Pavlova M et al. (2018) Investigation of Salmonella enteritidis outbreak in four kindergartens. Le infezioni in medicina 26:316-320

Phoebe Lostroh C, Lee CA (2001) The Salmonella pathogenicity island-1 type III secretion system. Microb Infect 3:1281-1291 doi:https://doi.org/10.1016/S1286-4579(01)01488-5

Quan G et al. (2019) Fimbriae and related receptors for Salmonella Enteritidis. Microb Pathog 126:357-362 doi:https://doi.org/10.1016/j.micpath.2018.10.025

Quinteiro-Filho WM et al. (2012) Heat stress impairs performance and induces intestinal inflammation in broiler chickens infected with Salmonella Enteritidis. Avian Pathol 41:421-427

doi:https://doi.org/10.1080/03079457.2012.709315

Rahn K et al. (1992) Amplification of an invA gene sequence of Salmonella typhimurium by polymerase chain reaction as a specific method of detection of Salmonella. Mol Cell Probes 6:271-279 doi:https://doi.org/10.1016/0890-8508(92)90002-F

Römling U, Bian Z, Hammar M, Sierralta WD, Normark S (1998) Curli fibers are highly conserved between Salmonella typhimurium and Escherichia coli with respect to operon structure and regulation. J Bacteriol 180:722-731

Salehi S, Howe K, Lawrence ML, Brooks JP, Bailey RH, Karsi A (2017) Salmonella enterica serovar Kentucky flagella are required for broiler skin adhesion and caco-2 cell invasion. Appl Environ Microbiol 83:e02115- 
Shah DH, Casavant C, Hawley Q, Addwebi T, Call DR, Guard J (2012) Salmonella Enteritidis Strains from Poultry Exhibit Differential Responses to Acid Stress, Oxidative Stress, and Survival in the Egg Albumen. Foodborne Pathogens and Disease 9:258-264 doi:https://doi.org/10.1089/fpd.2011.1009

Sterzenbach T et al. (2013) A novel CsrA titration mechanism regulates fimbrial gene expression in Salmonella typhimurium. The EMBO Journal 32:2872 doi:https://doi.org/10.1038/emboj.2013.206

Tanabe Y, Wada T, Ono K, Abo T, Kutsukake K (2011) The transcript from the $\sigma^{28}$-dependent promoter is translationally inert in the expression of the $\sigma^{28}$-encoding gene flia in the fliaz operon of Salmonella enterica serovar Typhimurium. J Bacteriol 193:6132 doi:https://doi.org/10.1128/JB.05909-11

Vonaesch P, Sellin ME, Cardini S, Singh V, Barthel M, Hardt WD (2014) The Salmonella Typhimurium effector protein SopE transiently localizes to the early SCV and contributes to intracellular replication. Cell Microbiology 16:1723-1735 doi:https://doi.org/10.1111/cmi.12333

Wagner C, Hensel M (2011) Adhesive mechanisms of Salmonella enterica. In: Linke D, Goldman A (eds) Bacterial Adhesion, vol 715. Springer, Dordrecht, Advances in Experimental Medicine and Biology, pp 17-34. doi:https://doi.org/10.1007/978-94-007-0940-9_2

Wright AP, Richardson L, Mahon BE, Rothenberg R, Cole DJ (2015) The rise and decline in Salmonella enterica serovar Enteritidis outbreaks attributed to egg-containing foods in the United States, 1973-2009. Epidemiol Infect 144:810-819 doi:https://doi.org/10.1017/S0950268815001867

Zhang J et al. (2013) Transcriptome analysis of Cymbidium sinense and its application to the identification of genes associated with floral development. BMC Genomics 14:279 doi:https://doi.org/10.1186/1471-2164-14279

Zhu C, Meng X, Duan X, Tao Z, Gong J, Hou H, Zhu G (2013) SEF14 fimbriae from Salmonella enteritidis play a role in pathogenitic to cell model in vitro and host in vivo. Microb Pathog 64:18-22 doi:https://doi.org/10.1016/j.micpath.2013.07.002

\section{Tables}


Table 1

Primer pairs used for qRT-PCR validation.

\begin{tabular}{|c|c|c|c|}
\hline $\begin{array}{l}\text { Gene } \\
\text { name }\end{array}$ & Gene annotation & Primer pair & Reference \\
\hline \multirow[t]{2}{*}{$\begin{array}{l}16 S \\
\text { rRNA }\end{array}$} & & 5'-CCTCAGCACATTGACGTTAC-3' & \multirow[t]{2}{*}{$\begin{array}{l}\text { (Eaves et al., } \\
\text { 2004) }\end{array}$} \\
\hline & & 5'-TTCCTCCAGATCTCTACGCA-3' & \\
\hline \multirow[t]{2}{*}{ sefC } & \multirow{2}{*}{$\begin{array}{l}\text { outer membrane fimbrial usher } \\
\text { protein }\end{array}$} & F,5'-GGCAGGTCCAAAACTATACA-3' & \multirow{2}{*}{$\begin{array}{l}\text { (Choudhury et } \\
\text { al., 2016) }\end{array}$} \\
\hline & & R,5'-GCGATAACGAAACACCATTT-3' & \\
\hline \multirow[t]{3}{*}{ sopE } & \multirow[t]{2}{*}{ type III secretion system, } & F,5'-ACACACTTTCCACGAGGAAGCG-3' & \multirow{3}{*}{$\begin{array}{l}\text { (El-Sharkawy } \\
\text { et al., 2017) }\end{array}$} \\
\hline & & R,5'-GGATGCCTTCTGATGTTGACTGG-3' & \\
\hline & secreted effector protein SopE & & \\
\hline \multirow[t]{2}{*}{ sopA } & secreted protein SopA & $\begin{array}{l}\text { F,5'- } \\
\text { ATCGATGGACTGTCATTGAATAATCAGC-3' }\end{array}$ & \multirow[t]{2}{*}{$\begin{array}{l}\text { (Raffatellu et } \\
\text { al., 2005) }\end{array}$} \\
\hline & & R,5'-ATCGATGGTTGAGGCTGGACTAC-3' & \\
\hline \multirow[t]{2}{*}{ rfbS } & \multirow[t]{2}{*}{ paratose synthase } & F,5'-ACATACTGTGATTGGCTTAG-3' & \multirow{2}{*}{$\begin{array}{l}\text { (Ren et al., } \\
2016)\end{array}$} \\
\hline & & R,5'-CATTGGCTCTTTCTTTGA - 3' & \\
\hline \multirow[t]{2}{*}{ ssel } & conserved hypothetical protein; & F,5'-AGGAAACAGAGCAAAATGAA-3' & \multirow{2}{*}{$\begin{array}{l}\text { (Liu et al., } \\
2011)\end{array}$} \\
\hline & deubiquitinase & R,5'-TAAATTCTTCGCAGAGCATC-3' & \\
\hline \multirow[t]{2}{*}{ fiml } & \multirow[t]{2}{*}{ major pilin protein } & F,5'-CCTTTCTCCATCGTCCTGAA-3')-3' & \multirow{2}{*}{$\begin{array}{l}\text { (Jothikumar et } \\
\text { al., 2003) }\end{array}$} \\
\hline & & R,5'-TGGTGTTATCTGCCTGACC-3') -3' & \\
\hline \multirow[t]{2}{*}{ pipB2 } & \multirow[t]{2}{*}{ exported protein } & F,5'-TCTTCCTGGTGAGAATAACG-3' & \multirow{2}{*}{$\begin{array}{l}\text { (Yin et al., } \\
2017)\end{array}$} \\
\hline & & R,5'-TTCGCATCTGAATAGTAAAGC-3' & \\
\hline \multirow[t]{4}{*}{ oatA } & $\begin{array}{l}\text { lipopolysaccharide } \\
\text { modification acyltransferase }\end{array}$ & $\begin{array}{l}\text { F, } 5^{\prime}- \\
\text { GTCAGCTTCCGGCGTGGCCGCGGATAACAA }\end{array}$ & \multirow{4}{*}{$\begin{array}{l}\text { (VanDrisse and } \\
\text { Escalante- } \\
\text { Semerena, } \\
\text { 2018) }\end{array}$} \\
\hline & & GAGAGAGTGTAGGCTGGAGCTGCTTC-3' & \\
\hline & & $\begin{array}{l}\text { R,5'- } \\
\text { AGATGCCTTCATCGAGTAGTTGGATATGTC }\end{array}$ & \\
\hline & & CAGCT ACATATGAATATCCTCCTTAG-3' & \\
\hline \multirow[t]{2}{*}{ csrA } & carbon storage regulator & F,5'-CTGGACTGCTGGGATTTTTC-3' & \multirow{2}{*}{$\begin{array}{l}\text { (Mizusaki et } \\
\text { al., 2008) }\end{array}$} \\
\hline & & R,5'-CATGATTGGCGATGAGGTC-3' & \\
\hline
\end{tabular}


Table 2

Classification of differentially expressed genes (DEGs) associated with virulence according to functions and structures when $S$. Enteritidis was coping with acid stress.

\begin{tabular}{|c|c|c|c|c|c|c|}
\hline Classification & Gene ID & Name & $\begin{array}{l}\text { Fold } \\
\text { change } \\
\left(\log _{2} F C\right)\end{array}$ & P-value & FDR & Description \\
\hline \multirow[t]{18}{*}{ flagella } & SEN1037 & flil & 1.32 & 1.47E-25 & $1.83 \mathrm{E}-24$ & $\begin{array}{l}\text { Flagellum-specific ATP } \\
\text { synthase Flil }\end{array}$ \\
\hline & SEN1038 & $\mathrm{fliH}$ & 1.24 & $4.52 E-24$ & $5.22 \mathrm{E}-23$ & $\begin{array}{l}\text { flagellar assembly } \\
\text { protein } \mathrm{H}\end{array}$ \\
\hline & SEN1039 & fliG & 1.44 & 4.59E-52 & $1.32 E-50$ & $\begin{array}{l}\text { flagellar motor switch } \\
\text { protein G }\end{array}$ \\
\hline & SEN1040 & fliF & 1.19 & $2.64 \mathrm{E}-38$ & $5.20 \mathrm{E}-37$ & $\begin{array}{l}\text { flagellar MS-ring } \\
\text { protein }\end{array}$ \\
\hline & SEN1046 & fliT & 1.30 & 2.71E-18 & $2.46 \mathrm{E}-17$ & $\begin{array}{l}\text { flagellar biosynthesis } \\
\text { protein FliT }\end{array}$ \\
\hline & SEN1048 & fliD & 1.48 & $\begin{array}{l}6.87 E- \\
258\end{array}$ & $\begin{array}{l}1.50 \mathrm{E}- \\
255\end{array}$ & $\begin{array}{l}\text { flagellar capping } \\
\text { protein }\end{array}$ \\
\hline & SEN1049 & flic & 2.13 & 0 & 0 & flagellin \\
\hline & SEN1051 & fliA & 1.19 & $8.45 \mathrm{E}-40$ & 1.71E-38 & $\begin{array}{l}\text { flagellar biosynthesis } \\
\text { sigma factor, partial }\end{array}$ \\
\hline & SEN1052 & fliZ & 1.13 & 1.10E-32 & 1.81E-31 & $\begin{array}{l}\text { flagella biosynthesis } \\
\text { protein Fliz }\end{array}$ \\
\hline & SEN1087 & cheY & 1.24 & 3.05E-22 & $3.26 \mathrm{E}-21$ & $\begin{array}{l}\text { chemotaxis regulatory } \\
\text { protein CheY }\end{array}$ \\
\hline & SEN1088 & cheZ & 1.19 & $1.65 \mathrm{E}-44$ & $3.96 \mathrm{E}-43$ & $\begin{array}{l}\text { chemotaxis regulator } \\
\text { CheZ }\end{array}$ \\
\hline & SEN1870 & $f l g F$ & 1.40 & 7.77E-26 & $9.80 \mathrm{E}-25$ & $\begin{array}{l}\text { flagellar basal body } \\
\text { rod protein FlgF }\end{array}$ \\
\hline & SEN1871 & $f l g E$ & 1.05 & $1.75 E-51$ & $4.96 \mathrm{E}-50$ & $\begin{array}{l}\text { flagellar hook protein } \\
\text { FlgE }\end{array}$ \\
\hline & SEN1873 & $f l g C$ & 1.37 & $9.56 \mathrm{E}-11$ & $5.46 \mathrm{E}-10$ & $\begin{array}{l}\text { flagellar basal body } \\
\text { rod protein FlgC }\end{array}$ \\
\hline & SEN1874 & $f l g B$ & 1.09 & $2.10 \mathrm{E}-08$ & $1.01 \mathrm{E}-07$ & $\begin{array}{l}\text { flagellar basal body } \\
\text { rod protein FlgB }\end{array}$ \\
\hline & SEN1875 & $f l g A$ & 1.43 & $4.84 \mathrm{E}-23$ & $5.36 \mathrm{E}-22$ & $\begin{array}{l}\text { flagellar basal body } \mathrm{P} \text { - } \\
\text { ring biosynthesis } \\
\text { protein FlgA }\end{array}$ \\
\hline & SEN1876 & $f l g M$ & 1.02 & $1.61 \mathrm{E}-10$ & $9.05 E-10$ & $\begin{array}{l}\text { anti-sigma-28 factor } \\
\text { FlgM }\end{array}$ \\
\hline & SEN1877 & $f l g N$ & 1.50 & $1.35 E-38$ & $2.68 E-37$ & $\begin{array}{l}\text { flagellar synthesis } \\
\text { protein FlgN }\end{array}$ \\
\hline
\end{tabular}




\begin{tabular}{|c|c|c|c|c|c|c|}
\hline Classification & Gene ID & Name & $\begin{array}{l}\text { Fold } \\
\text { change } \\
\left(\log _{2} \mathrm{FC}\right)\end{array}$ & P-value & FDR & Description \\
\hline & SEN3059 & aer & 1.12 & $1.96 \mathrm{E}-14$ & $1.42 \mathrm{E}-13$ & aerotaxis receptor \\
\hline & SEN4145 & bsmA & -2.21 & $\begin{array}{l}7.01 \mathrm{E}- \\
143\end{array}$ & $\begin{array}{l}6.31 \mathrm{E}- \\
141\end{array}$ & $\begin{array}{l}\text { biofilm stress and } \\
\text { motility protein A }\end{array}$ \\
\hline & SEN4298 & tsr & 1.37 & $\begin{array}{l}8.25 \mathrm{E}- \\
162\end{array}$ & $\begin{array}{l}8.99 \mathrm{E}- \\
160\end{array}$ & $\begin{array}{l}\text { methyl-accepting } \\
\text { chemotaxis protein I }\end{array}$ \\
\hline \multirow[t]{12}{*}{ fimbria } & SEN0146 & hofC & -1.46 & 0.007687 & 0.017094 & $\begin{array}{l}\text { type IV pilin biogenesis } \\
\text { protein }\end{array}$ \\
\hline & SEN0525 & fiml & -1.54 & 0.005139 & 0.011935 & major pilin protein \\
\hline & SEN0527 & fimD & -1.06 & 6.39E-07 & $2.62 \mathrm{E}-06$ & $\begin{array}{l}\text { outer membrane usher } \\
\text { protein SfmD }\end{array}$ \\
\hline & SEN0529 & fimF & 1.36 & 0.011403 & 0.024544 & fimbrial protein \\
\hline & SEN1977 & - & 1.23 & $5.29 \mathrm{E}-13$ & $3.51 \mathrm{E}-12$ & putative type IV prepilin \\
\hline & SEN2145B & yehD & 2.02 & $6.04 \mathrm{E}-12$ & 3.78E-11 & fimbrial subunit protein \\
\hline & SEN2875 & pagC & 3.13 & $7.28 \mathrm{E}-37$ & $1.36 \mathrm{E}-35$ & $\begin{array}{l}\text { outer membrane } \\
\text { protein }\end{array}$ \\
\hline & SEN3463 & IpfA & 2.09 & 0.002614 & 0.006374 & $\begin{array}{l}\text { long polar fimbrial } \\
\text { protein A precursor }\end{array}$ \\
\hline & SEN4247 & $\operatorname{sef} A$ & 1.54 & $5.32 \mathrm{E}-91$ & $2.72 \mathrm{E}-89$ & fimbrial protein \\
\hline & SEN4249 & sefC & 1.90 & $3.12 \mathrm{E}-06$ & $1.18 \mathrm{E}-05$ & $\begin{array}{l}\text { outer membrane } \\
\text { fimbrial usher protein }\end{array}$ \\
\hline & SEN4251 & virF & 1.29 & 0.000154 & 0.00046 & $\begin{array}{l}\text { fimbrial operon } \\
\text { positive regulatory } \\
\text { protein }\end{array}$ \\
\hline & SEN4350 & IpfB & 1.37 & 0.005139 & 0.011935 & $\begin{array}{l}\text { fimbrial assembly } \\
\text { chaperone SthB }\end{array}$ \\
\hline \multirow[t]{5}{*}{ invasion } & SEN0454 & hha & 1.39 & 1.06E-09 & 5.60E-09 & $\begin{array}{l}\text { hemolysin expression- } \\
\text { modulating protein }\end{array}$ \\
\hline & SEN1155 & sopE & 1.48 & 0.010733 & 0.023208 & $\begin{array}{l}\text { type III secretion } \\
\text { system, secreted } \\
\text { effector protein SopE }\end{array}$ \\
\hline & SEN1454 & $\operatorname{sifB}$ & 1.22 & 0.011591 & 0.024871 & $\begin{array}{l}\text { secreted effector } \\
\text { protein }\end{array}$ \\
\hline & SEN1627 & ssaQ & 1.43 & 7.78E-05 & 0.000243 & $\begin{array}{l}\text { type III secretion } \\
\text { system protein }\end{array}$ \\
\hline & SEN1645 & sseC & 1.19 & 0.006667 & 0.014997 & $\begin{array}{l}\text { translocation } \\
\text { machinery component }\end{array}$ \\
\hline
\end{tabular}




\begin{tabular}{|c|c|c|c|c|c|c|}
\hline Classification & Gene ID & Name & $\begin{array}{l}\text { Fold } \\
\text { change } \\
\left(\log _{2} \mathrm{FC}\right)\end{array}$ & P-value & FDR & Description \\
\hline & SEN1653 & $\operatorname{rcs} C$ & 1.01 & $5.52 \mathrm{E}-08$ & $2.52 \mathrm{E}-07$ & $\begin{array}{l}\text { secretion system } \\
\text { regulator: Sensor } \\
\text { component }\end{array}$ \\
\hline & SEN2065 & sopA & -1.13 & 2.86E-06 & 1.09E-05 & secreted protein SopA \\
\hline & SEN2269 & ssel & 1.19 & $2.45 \mathrm{E}-05$ & $8.25 \mathrm{E}-05$ & $\begin{array}{l}\text { conserved hypothetical } \\
\text { protein; deubiquitinase }\end{array}$ \\
\hline & SEN2624 & pipB2 & 1.57 & $2.11 \mathrm{E}-13$ & $1.44 \mathrm{E}-12$ & exported protein \\
\hline & SEN2784 & sopD & 2.04 & 1.57E-05 & $5.40 \mathrm{E}-05$ & $\begin{array}{l}\text { Sop effector protein } \\
\text { SopD }\end{array}$ \\
\hline & SEN3219 & fis & 1.29 & 4.63E-30 & $6.85 E-29$ & $\begin{array}{l}\text { Fis family } \\
\text { transcriptional } \\
\text { regulator }\end{array}$ \\
\hline & SEN3371 & - & 1.12 & $1.94 \mathrm{E}-41$ & 4.19E-40 & $\begin{array}{l}\text { pathogenicity island } \\
\text { protein }\end{array}$ \\
\hline \multirow[t]{10}{*}{ lipopolysaccharide } & SEN1893 & $I p x L$ & -1.03 & 2.00E-13 & 1.37E-12 & $\begin{array}{l}\text { lipid A biosynthesis } \\
\text { lauroyl acyltransferase }\end{array}$ \\
\hline & SEN2082 & $r f b K$ & 1.17 & $1.59 \mathrm{E}-13$ & 1.10E-12 & phosphomannomutase \\
\hline & SEN2085 & $r f b U$ & 1.43 & $9.82 \mathrm{E}-13$ & $6.42 \mathrm{E}-12$ & mannosyl transferase \\
\hline & SEN2085C & $r f b E$ & 1.67 & $4.80 \mathrm{E}-44$ & $1.14 \mathrm{E}-42$ & $\begin{array}{l}\text { CDP-paratose 2- } \\
\text { epimerase }\end{array}$ \\
\hline & SEN2085D & $r f b S$ & 2.30 & $2.23 E-29$ & $3.21 \mathrm{E}-28$ & paratose synthase \\
\hline & SEN2378 & oatA & 1.98 & 0.000514 & 0.001401 & $\begin{array}{l}\text { lipopolysaccharide } \\
\text { modification } \\
\text { acyltransferase }\end{array}$ \\
\hline & SEN2387 & $I p x P$ & 1.05 & $1.36 \mathrm{E}-08$ & $6.64 \mathrm{E}-08$ & $\begin{array}{l}\text { lipid A biosynthesis } \\
\text { palmitoleoyl } \\
\text { acyltransferase }\end{array}$ \\
\hline & SEN3533 & IfaF & -1.20 & $1.78 \mathrm{E}-31$ & $2.80 \mathrm{E}-30$ & $\begin{array}{l}\text { ADP-heptose:LPS } \\
\text { heptosyltransferase II }\end{array}$ \\
\hline & SEN3535 & $r f a L$ & 1.37 & $4.24 \mathrm{E}-48$ & $1.14 \mathrm{E}-46$ & O-antigen ligase \\
\hline & SEN3539 & rfaJ & 1.78 & $2.36 \mathrm{E}-20$ & 2.33E-19 & $\begin{array}{l}\text { lipopolysaccharide 1,2- } \\
\text { glucosyltransferase }\end{array}$ \\
\hline \multirow[t]{2}{*}{ Regulators } & SEN1532 & marA & 2.37 & $4.05 E-36$ & 7.32E-35 & $\begin{array}{l}\text { DNA-binding } \\
\text { transcriptional } \\
\text { activator MarA }\end{array}$ \\
\hline & SEN2667 & CsrA & 1.23 & $6.61 \mathrm{E}-14$ & 4.66E-13 & $\begin{array}{l}\text { carbon storage } \\
\text { regulator }\end{array}$ \\
\hline
\end{tabular}




\begin{tabular}{|lllllll|}
\hline Classification & Gene ID & Name & $\begin{array}{l}\text { Fold } \\
\text { change } \\
\left(\log _{2} \mathrm{FC}\right)\end{array}$ & P-value & FDR & Description \\
\hline & SEN4035 & soxS & 1.27 & $7.69 \mathrm{E}-06$ & $2.76 \mathrm{E}-05$ & $\begin{array}{l}\text { DNA-binding } \\
\text { transcriptional } \\
\text { regulator SoxS }\end{array}$ \\
\hline
\end{tabular}

Figures

\section{Volcano plot}

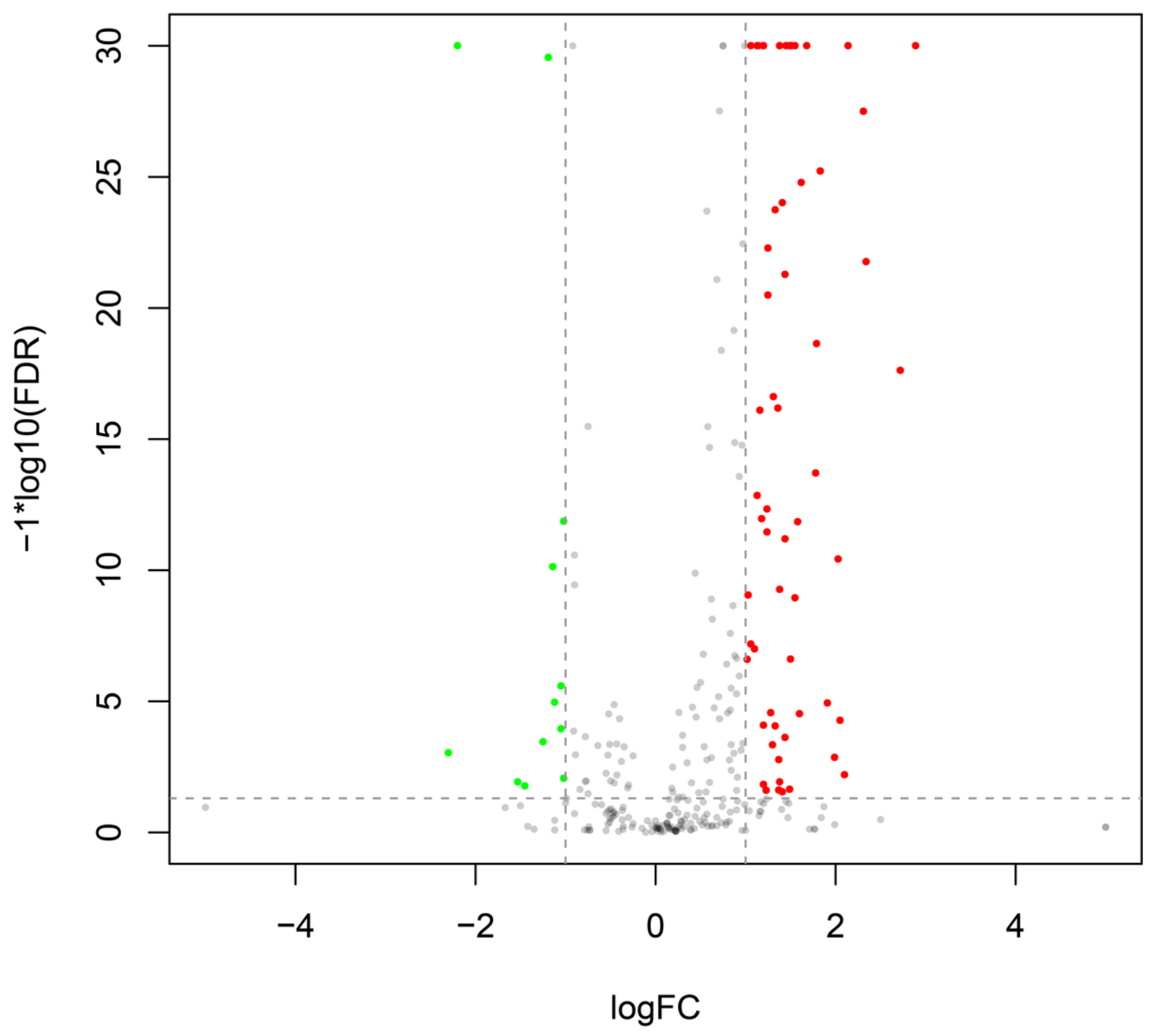




\section{Figure 1}

Volcano plots diagram of DEGs associated with virulence between acid stressed and unstressed S. Enteritidis. Red spots in the right part: up-regulated genes; green spots in the left part; down-regulated genes; black spots in the middle part: genes with insignificant changes between the stressed and unstressed.

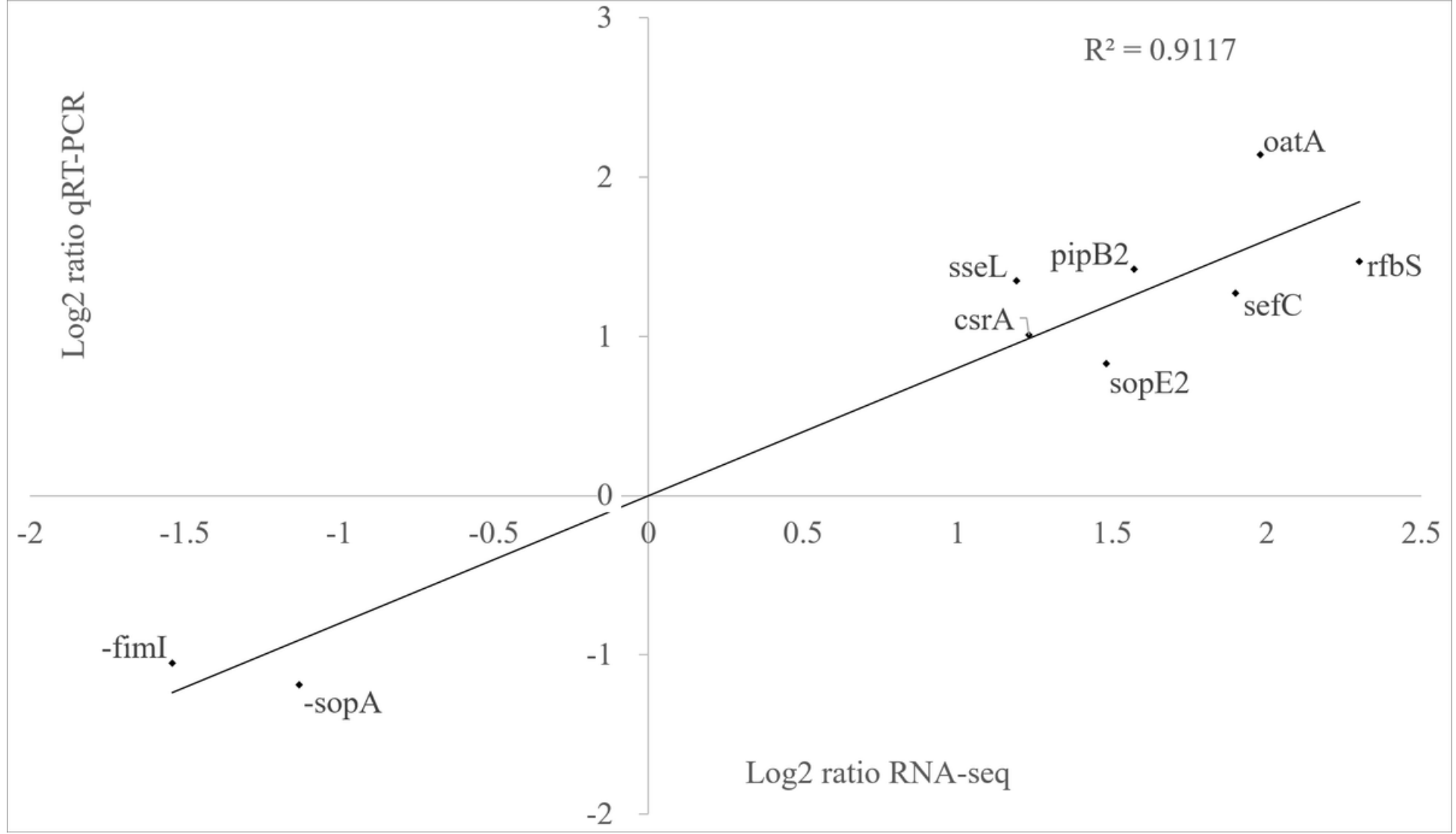

Figure 2

qRT-PCR validation. X: the log2 fold change according to RNA-seq; Y: the log2 fold change according to qRTPCR. 


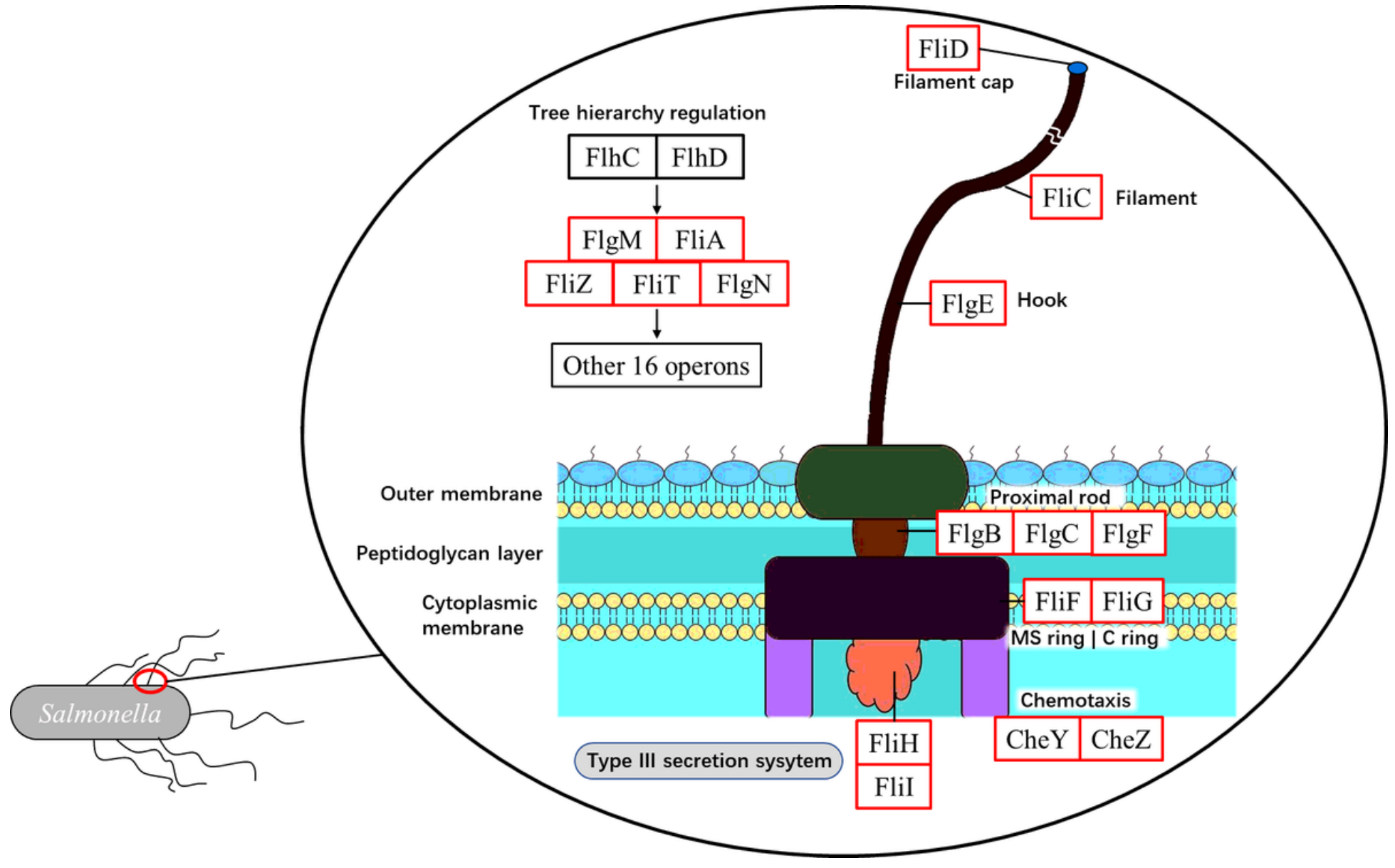

Figure 3

Flagellar assembly and chemotaxis were up-regulated under under acid stress in S. Enteritidis. Red boxes: upregulated genes; black boxes: genes with insignificant changes between the stressed and unstressed. 


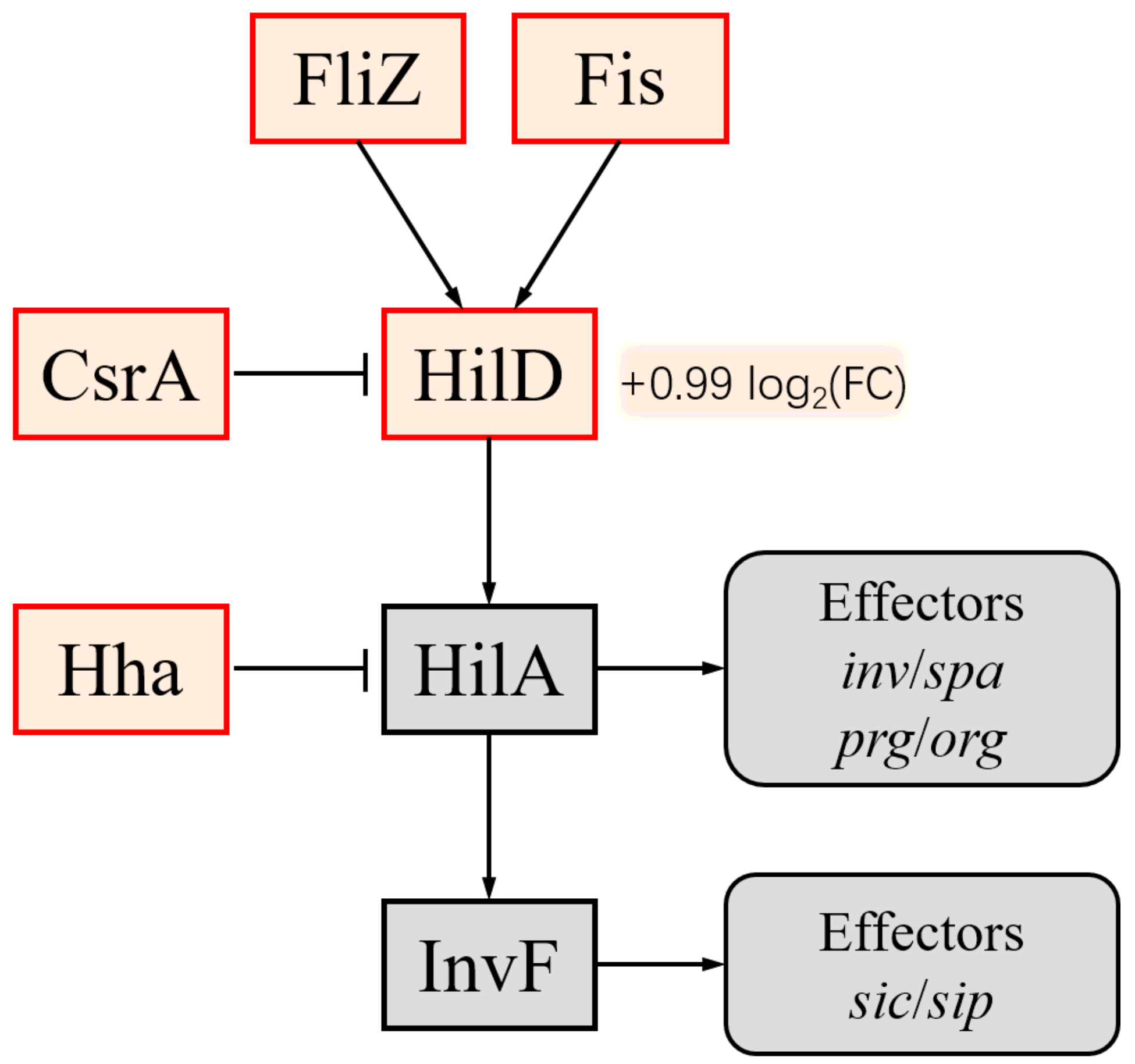

Figure 4

Model proposing the possible mechanism of hierarchy regulation of genes involved in invasion under acid stress condition. Common arrows: activation regulation; blunt-end arrows: repression regulation; Red boxes: up-regulated genes; black boxes: genes with insignificant changes between the stressed and unstressed (Fabrega and Vila 2013) 